\title{
SYSTEMS APPLIED IN INDONESIA IN GIVING PATENT RIGHTS IN INVENTORS
}

\section{Kiki Tarnando}

155100041

Fakultas Komputer, 448757263

kikitarnando.student@umitra.ac.id

\begin{abstract}
Patent is a special right granted by the State to the inventor of his invention in the field of technology, which for a certain period of time carries out its own invasion or gives approval to other parties to carry out it. The definition of patent itself is imposed in the Act which is located in article 1 paragraph 1 of the Law on patents.

Inventor is a person who individually or several people who jointly implement the ideas poured into activities that produce inventions (Findings).

The application of the Patent Rights itself in Indonesia is assessed from the first inventory system to register their products for patenting.
\end{abstract}

Keywords: Patents, and Inventor

\section{A. INTRODUCTION}

Patent is a special right granted by the State to the inventor of his invention in the field of technology, which for a certain period of time carries out its own invasion or gives approval to other parties to carry out it. The definition of patent itself is imposed in the Act which is located in article 1 paragraph 1 of the Law on patents.
The word patent comes from the English patent, which originally came from the word patere which means opening up (for public examination), and also comes from the term letter patent, which is a decree issued by the kingdom that gives exclusive rights to individuals and certain business actors. From the definition of the word patent itself, the patent concept encourages inventors to open knowledge for the betterment of society and instead, inventor 
gets exclusive rights for a certain period. Given that the patent does not regulate who has to do a patented invention, the patent system is not considered a monopoly right.

At present there are several international agreements governing patent law. Among other things, the WTO Agreement on TRIPs which is followed by almost all countries.

Patent rights are territorial, that is, binding only in certain locations. Thus, to obtain patent protection in several countries or regions, a person must submit a patent application in each of these countries or regions.

In general, there are three broad categories of subject matter that can be patented: processes, machines, and items produced and used. The process includes algorithms, business methods, most software, medical techniques, sports techniques and the like. The machine includes tools and apparatus.

The goods produced include mechanical devices, electronic devices and material compositions such as chemistry, medicine, DNA, RNA, and so on. Specifically human embryonic stem (hES) cannot be patented in the European Union.

There are 2 types of systems used in patent registration

, that is :
1. First to File system, this system in patent registration is carried out for those who register first for new inventions in accordance with the requirements.

2. The First to Invent system, is a system that provides patents for those who find the first innovation in accordance with predetermined requirements.

In conducting patent rights, Indonesia itself applies to the first system, the First to File system, where the inventor who first registers a product has the right to register a patent with terms and conditions in force.

\section{B. CONCLUSION}

Patent is a special right granted by the State to the inventor of his invention in the field of technology, which for a certain period of time carries out its own invasion or gives approval to other parties to carry out it. The definition of patent itself is imposed in the Act which is located in article 1 paragraph 1 of the Law on patents.

Inventor is a person who individually or several people who jointly implement the ideas poured into activities that produce inventions (Findings). 
The application of the Patent Rights itself in Indonesia is assessed from the first inventory system to register their products for patenting.

\section{ACKNOWLEDGEMENT \\ University Of Indonesia University Of Mitra Indonesia Telkom University University Of Mellbourne Saitama University}

\section{REFERENCE(Based ISO 690 )}

A. S. Putra And O. M. Febriani, "Knowledge
Online Application In Pdam Lampung Province," In Prosiding International Conference On Information Technology And Business (Icitb), 2018, Pp. 181-187.

[2] A. S. Putra, O. M. Febriani, And B. Bachry, "Implementasi Genetic Fuzzy System Untuk Mengidentifikasi Hasil Curian Kendaraan Bermotor Di Polda Lampung," J. Sist. Inf. Dan Manaj. Basis Data, Vol. 1, No. 1, Pp. 21-30, 2018.

[3] O. M. Febriani And A. S. Putra, "Sistem Informasi Monitoring Inventori Barang Pada Balai Riset Standardisasi Industri Bandar Lampung," J. Inform., Vol. 13, No. 1, Pp. 90-98, 2014.

[4] Putra, Arie Setya. "2018 Artikel Struktur Data, Audit Dan Jaringan Komputer." (2018).

[5] Putra, A. S. (2018, July 17). Paperplain Fundamental Create Application With Borland Delphi 7.0 University Of Mitra Indonesia. Retrieved From Osf.Io/Pbrn9.

\section{E. REFERENCE(Based APA )}

Putra, A. S., Aryanti, D. R., \& Hartati, I. (2018, November). Metode SAW (Simple Additive Weighting) sebagai Sistem Pendukung Keputusan Guru 
Berprestasi (Studi Kasus: SMK Global Surya). In Prosiding Seminar Nasional Darmajaya (Vol. 1, No. 1, pp. 85-97).

Sari, D. P., Febriani, O. M., \& Putra, A. S. (2018, November). Perancangan Sistem Informasi SDM Berprestasi pada SD Global Surya. In Prosiding Seminar Nasional Darmajaya (Vol. 1, No. 1, pp. 289-294).

Putra, A. S. (2018). Paperplain: Execution Fundamental Create Application With Borland Delphi 7.0 University Of Mitra Indonesia.

Putra, A. S., Sukri, H., \& Zuhri, K. Sistem Monitoring Realtime Jaringan Irigasi Desa (JIDES) Dengan Konsep Jaringan Sensor Nirkabel. IJEIS (Indonesian Journal of Electronics and Instrumentation Systems), 8(2), 221232.

Darmawan, A., Yuliawati, D., Marcella, O., \& Firmandala, R. (2016). Sistem Absensi dan Pelaporan Berbasis Fingerprint dan SMS Gateway. EXPLORE, 7(1).

Febriani, O. M., Wahyuni, T., \& Yusuf, S. (2017). DESIGN OF WEBSITE-BASED INFORMATION SYSTEM FOR EDOCUMENT ADMINISTRASI IN THE COMMUNITY SERVICE UNIT (A Case Study at Rajabasa District). INTERNATIONAL JOURNAL OF COMPUTERS \& TECHNOLOGY, 16(7), 7010-7020.

Febriani, O. M., \& Wahyuni, T. (2017, October). PERANCANGAN SISTEM E-DOCUMENT ADMINISTRASI
LOGBOOK PENELITIAN PADA UNIT LAYANAN DI BANDAR LAMPUNG. In Prosiding Seminar Nasional Darmajaya (Vol. 1, No. 1, pp. 187-194).

Febriani, O. M., \& Permadi, A. B. (2017). Implementasi Sistem Aplikasi Data Bimbingan dan Pelanggaran Siswa pada Sekolah Menengah Atas di Lampung Tengah dengan Metode Analisis dan Desain Sistem Terdistribusi (SSAD). EXPERT, 7(1).

Febriani, O. M., \& Ambarwati, L. (2015). PERANCANGAN APLIKASI PENGOLAHAN DATA PENJUALAN UKM KELANTING KHAS TELO DESA SIDOHARJO KECAMATAN JATI AGUNG KABUPATEN LAMPUNG SELATAN. Jurnal Teknologi Informasi dan Bisnis Pengabdian Masyarakat Darmajaya, 1(1), 77-95.

Febriani, O. M. (2015). Rancang Bangun Aplikasi Ecommercemenggunakan Freewebstore pada UKM Kelanting di Desa Sidoharjo Lampung Selatan. Prosiding Sembistek 2014, 1(02), 446-458. 